\title{
Gender Dynamics of Rice Farming in Pendulonan, Munai, Lanaodel Norte
}

\author{
Layliah M. Ayonan and Aldrees Ansary B. Guro \\ College of Agriculture, Mindanao State University, \\ Main Campus- Marawi City
}

\begin{abstract}
This study determined the demographic profile of farmers at Pendulonan, MunaiLanaodel Norte and their farming practices. Specifically it measures the performance in gender dynamics of farmers and the problems they encountered rice farming. There were fifty (50) farmers participants randomly selected from barangay Pendulonan, MunaiLanaodel Norte. The data were collected through survey questionnaire and interviews. Findings revealed thatmost farmers of Barangay Pendulonan, MunaiLanao del Norte are 41 to 50 years old, male, married, incomplete elementary level, have a household size of more than 6 members, monthly income of 5000 to 10,000, farm size of 1 to 2 hectares with share cropping, and have average farming land from 11 to 20 years. Most of them agree at level of rice production in rice classification is irrigated from a river as source of water, and type of land are upland. Furthermore, they agree the roles in gender dynamics as farm manager, decision maker, marketing the rice product, harvester, and paid worker. Common problems they encountered are lack information and insufficient agricultural extension activities, lacks of knowledge and lacks of proper training in rice farming.
\end{abstract}

Keywords: gender dynamic, farmer, rice farming.

\section{Introduction}

Farming is a common source of living all over the world. Mostly, men will do the agricultural farming activities. The study Ogato, Boon and Subramani (2009) about gender roles in crop production and management practices in Ethiopia revealed that female farmers contributed higher in crop production and management compared to male farmers, but both of them has equal roles in marketing the farm products, and other agricultural activities such as planting, soil conservation, application of fertilizers and herbicides.

Njuki, Kaaria, Chamunorwa and Chiuri (2011) analyze what influences the distribution of income between men and women particularly on the type of commodity and market approaches. Their findings indicate that women controlled commodities with lower revenues while men controlled the commodities with high revenues. However, in Uganda, Ghana and Bangladesh, women are less adaptive in agriculture due to resources constraint and male domination (Jost, Kyazze, Naab, Neelormi, Kinyangi, and Zougmore, 2014). Findings of the study conducted by Oldrup (2002) showed that farming women encountered dilemmas in reconciling farm practices with their norms and their lack of knowledge in farming.

In the Philippine context, agricultural farming is significantly importance in Philippine economy. Twenty percent $(20 \%)$ of the Gross domestic Products (GDP) of the Philippine economy is contributed by agricultural farming. In rural areas, women are also involved in crop productions and other agricultural activities. However, women participation in agricultural activities particularly in most developing countries is undervalued. Quisumbing, et al. (2014) said that the underperformance of agriculture is because women farmers have no equal access to agricultural resources and opportunities. Swaminathan, et al. (2012) mentioned that the key drivers of gender 
dynamics in agriculture is inter and intra-household differences and how female-headed households are often poorer and more disadvantaged.

Filipino women are active economic actors in nature and contributed greatly in food production and business enterprise. Since agriculture is one of the largest sectors of women's employment in the Philippines, there is a need to empower women to make decision about planting materials and inputs to make agriculture more productive. Study of Pandey, et al. (2010) on gender roles in rice farming in the Philippines found out that gender relations within households are strongly influenced by social, cultural, economic circumstances, family structure, and the degree of labor participation in the marketplace. According to Quisumbing, et al. (2014), women comprise about $43 \%$ of the agricultural labor force in developing countries, while Pandey, et al. (2010) estimated $32 \%$ female to male ratio in agricultural labor force in the Philippines.

According to Miralao (1992) there has been an increase of female-headed farm in the Philippines particularly among widowed women. Despite of such increase female-headed farm households encountered constraints in farming particularly women's ability to improve yield, profit, and efficiency in agriculture. Given the aforesaid conditions, the researchers are motivated to assess the impact of gender dynamics of rice farming. Specifically, investigated how gender affects net farm income, total farm output, farming efficiency, production costs, and total household income. Conducted in the largely agricultural locale of Pendulonan, Munai, Lanaodel Norte, this study aims to uncover information leading to further understanding of rice farming in the perspective of gender dynamics.

Generally, this study aims to evaluate the gender dynamics of farmers in rice farming in Pendulonan, Munai, Lanaodel Norte. Specifically, it sought to answer the following questions:

1. What is the demographic profile of the farmers at Pendulonan, Munai, Lanao del Norte in terms of age, gender, marital status, highest educational attainment, household family size, household income, farm size, and farm land status?

2. What are the practices of rice farmers at Pendulonan, Munai, Lanao del Norte in terms of rice classification, irrigation sources, and land type?

3. What are the specific roles of male and female farmers in rice farming at Pendulonan, Munai, Lanao del Norte?

4. What are the problems encountered by male and female farmers at Pendulonan, Munai, Lanaodel Norte?

The results of this study helps in understanding the roles of male and female farmers in rice farming at Pendulonan, Munai, Lanaodel Norte. Findings may also help researchers to determine the variables that affect the effectiveness of gender dynamics in rural areas and the solution to its entailing problems. Moreover, as this study provide knowledge about the gender dynamics in rice farming at Pendulonan, Munai, Lanao del Norte, the results may be useful to extension workers, agriculturists, and other professionals handling agriculture programs. Through the findings of this study, agricultural planner may improve the crafting and implementation of agriculture programs based on how gender dynamics influence rice farming. As a result, status of rice production would have a greater propensity to progress, and this would help elevate the economic condition of the farmers in the community.

\section{Methods}

\section{Participants}

This study was conducted in the province of Lanao del Norte, particularly in Barangay Pendulonan in the municipality of Munai, Lanao Del Norte. This province is a rugged province that ranges from the coastal shorelines in the north to the high plateaus and mountains in the south located in Northern Mindanao. The respondents of the study were the Maranao rice farmers from Pendulonan, Munai, Lanao Del Norte. The sample was composed of fifty (50) farmers, which was a mixture of male and female individuals. Total enumeration was employed to select the sample.

\section{Design}

The study is a descriptive type of research, which focuses on the demographic and socioeconomic profiles of rice farmers, the level of productivity of different genders, and rice farming practices with 
respect to gender as well as the problems encountered in by rice farmers. The survey method was employed in this study to collect the necessary data.

\section{Instrument}

The data of this study were gathered through the use of a semi-structured survey questionnaire. The survey questionnaire consisted of four (4) main parts. The first part included farmers-related factors while the second part was composed of level of rice production. The third part determined the rules of gender dynamics performed in rice farming in the last part identified the problems encountered by the farmers an interview was also conducted by the researchers. For easy understanding, the questions in the interview schedule were translated into Maranao dialect.

\section{Procedures}

Prior to conducting the study, communication was sent to the Barangay Chairman seeking approval to conduct the study in the locality. Then a courtesy call was done with the office of the Barangay Chairman to discuss with him the purpose of the study. After that, the researchers then distributed to groups and individuals in a house-to-house manner. After the retrieval of the questionnaires, the respondents were set for the interview. Aside from the data gathered through survey and interview, secondary data were also obtained from research studies and other reading materials such as books and other references. In addition, the data gathered were limited only to the gender roles of male and female farmers and their products from rice farming. Furthermore, the findings of the study may be applicable to the farmers of Pendulonan, Munai, Lanaodel Norte and could not be generalized to other rice-farmers in other areas.

\section{Result and Discussion}

\section{Farmers-Related Factors}

Age

More than a third $(38 \%)$ of the respondents were 41 to 50 years old while a third $(34 \%)$ of them were 31 to 40 years old. Additionally, a fifth $(20 \%)$ of the sample were as young as 20 to 30 years old/ and less than one eight (4\%) of them were 61 years old and above (Table 1). Age of farmers will affect its productivity. As they grow older their productivity decreases. Base on the results of the survey, the largest portion of the sample were composed of farmers who were 41 to 50 years old. Thus, there is a need for more participation from the younger generation of farmers in order to improve the workforce.

Table1: Frequency and Percentage Distribution of the Respondents according to Age

\begin{tabular}{lll}
\hline Age & Frequency (f) & Percentage $\mathbf{( \% )}$ \\
\hline 20 to 30 & 10 & 20 \\
31 to 40 & 17 & 34 \\
41 to 40 & 19 & 38 \\
51 to 60 & 2 & 4 \\
61 and above & 2 & 4 \\
\hline Total & $\mathbf{5 0}$ & $\mathbf{1 0 0}$ \\
\hline
\end{tabular}

\section{Gender}

Most respondents $(62 \%)$ are male while only a third $(38 \%)$ are female, the data imply that rice farming and production in the locality is participated by more male farmer than female ones, thus, an imbalance in gender dynamics. This may suggest that male farmers are more dominant and that they are the ones more involved in the management of the rice farming. Research study of RDoss (2001) revealed that men were mainly to adopt easily in terms of improving crop varieties and farm management than women farmers. The findings also revealed that gender is dynamic particularly on responsibilities engagement. Moreover, female farmers have poor access to agricultural extension and training programs thus, they have least strategies in farming and coping mechanisms on farms related problems (Mehar, Mittal and Prasad, 2016). Raynolds (2002) mentioned in her study that there is a continuous debate on gender issues in farming. Gasson and Winter (1992) study pointed out that husband and wives relationship in farming greatly varies considering that wives are less involved in farming than husbands do. 
Table 2: Frequency and Percentage Distribution of the Respondents according to Gender

\begin{tabular}{lll}
\hline Gender & Frequency (f) & Percentage (\%) \\
\hline Male & 31 & 62 \\
Female & 19 & 38 \\
\hline Total & $\mathbf{5 0}$ & $\mathbf{1 0 0}$ \\
\hline
\end{tabular}

\section{Marital Status}

More than three-fourths $(86 \%)$ of the respondents are married while less than one-eight $(8 \%)$ of them are separated. Moreover, less than one-eight (4\%) of them are widowed and another less than one-eight $(2 \%)$ of them are single. This implies that most of the respondents are married, thus, they need more income to sustain their families.

Table 3: Frequency and Percentage Distribution of the Respondents according to Marital status

\begin{tabular}{lll}
\hline Marital Status & Frequency (f) & Percentage (\%) \\
\hline Single & 1 & 2 \\
Married & 43 & 86 \\
Separated & 4 & 8 \\
Widow/Widower & 2 & 4 \\
\hline Total & $\mathbf{5 0}$ & $\mathbf{1 0 0}$ \\
\hline
\end{tabular}

\section{Highest Educational Attainment}

More than half $(56 \%)$ of the respondents have an incomplete elementary education and more than one-fourth $(26 \%)$ have not finished high school. Lastly, more than one-sixth $(18 \%)$ have no formal schooling. The data show that all respondents were not able to attain any professional degree or mid-level skills since they only reached basic education, with high school as highest.

Table 4: Frequency and Percentage Distribution of the Respondents according to Highest Educational Attainment

\begin{tabular}{lll}
\hline $\begin{array}{l}\text { Highest } \quad \text { Educational } \\
\text { Attainment }\end{array}$ & Frequency (f) & Percentage (\%) \\
\hline Incomplete Elementary & 28 & 56 \\
Incomplete Secondary & 13 & 26 \\
Incomplete Tertiary & 0 & 0 \\
No Formal Schooling & 9 & 18 \\
\hline Total & $\mathbf{5 0}$ & $\mathbf{1 0 0}$ \\
\hline
\end{tabular}

\section{Household Family Size}

More than half $(54 \%)$ of the respondents have a household size of more than 6 members, more than one third $(36 \%)$ of them have a household size between 4 to 6 members, while less than one-eight $(10 \%)$ have a household size between 1 to 3 members. This reveals that many of the respondents have many hands to help them in their farms. However, there may be a downside to such because there are many members of the family to support in terms of basic needs. Nevertheless, their large family size may help them increase productivity in farming, granted that all of them work for their farms.

Table 5: Frequency and Percentage Distribution of the Respondents according to House Hold Family Size

\begin{tabular}{lll}
\hline Household Income & Frequency (f) & Percentage (\%) \\
\hline Small (1 to 3 members) & 5 & 10 \\
Average (4 to 6 members) & 18 & 36 \\
Large (more than 6 members) & 27 & 54 \\
\hline Total & $\mathbf{5 0}$ & $\mathbf{1 0 0}$ \\
\hline
\end{tabular}

\section{Household Monthly Net Income}

More than half $(52 \%)$ of the respondents have a monthly income of 5000 to 10,000 and some onefifth $(24 \%)$ of them have a monthly income of 3000 to 5000 . Finally, more than fifth $(24 \%)$ also have a monthly income of 10,000 to 15,000 . This reveals that many of the respondents may find difficulty in terms of finances in that their income may not be sufficient with respect to their family 
size. Rice farming and production does not automatically provide income in a short period of time and this may cause shortages in supply of basic needs. The respondents might have other income generating endeavors in of the income from rice farming.

Table 6: Frequency and Percentage Distribution of the Respondents according to Household Monthly Income

\begin{tabular}{|ccc|}
\hline Household income & Frequency (f) & Percentage (\%) \\
\hline 3,000 to 5,000 & 12 & 24 \\
\hline 6,000 to 10,000 & 26 & 52 \\
\hline 11,000 to 15,000 & 12 & 24 \\
\hline
\end{tabular}

\section{Farm Size}

More than half $(56 \%)$ of the respondents have a farm size of 1 to 2 hectares and less than half $(40 \%)$ have less a hectare. Also, less than one-eight (4\%) of the respondents have 3 to 4 hectares while no one owns 5 hectares and beyond. The data imply that most of the respondents have 1 to 2 hectares of land of farm, which means the farmers are expected to have a considerably small income that may only suffice the basic needs of their family. This further reflects their monthly income in the previous table.

Table 7: Frequency and Percentage Distribution of Respondents according to Farm Size

\begin{tabular}{|c|c|c|}
\hline $\begin{array}{ll}\text { Highest } & \text { Educational } \\
\text { Attainment } & \\
\end{array}$ & Frequency (f) & Percentage $(\%)$ \\
\hline Below 1 hectare & 20 & 40 \\
\hline 1 to 2 hectares & 28 & 56 \\
\hline 3 to 4 hectares & 2 & 4 \\
\hline 5 hectares and above & - & - \\
\hline Total & 50 & 100 \\
\hline
\end{tabular}

\section{Farm Land Status}

Less than two-thirds (62\%) of the respondents do share cropping while almost a third (32\%) are land owners. Less than one-eight $(2 \%)$ are tenants. The data imply that most of the respondents do share cropping, which further affirms the previous results that they are expected to gain a considerably small income from farming. Nevertheless, the small number of land owners may possibly enjoy the benefits of farm ownership because they do not need to spend for rentals and other expenses expected of tenants and share croppers.

Table 8: Frequency and Percentage Distribution of Respondents according to Farm Land Status

\begin{tabular}{lll}
\hline Farm Land Status & Frequency $\mathbf{( f )}$ & Percentage $\mathbf{~} \% \mathbf{)}$ \\
\hline Tenant & 1 & 2 \\
Landless Tenant & - & - \\
Rental Tenant & 2 & 4 \\
Land Owner & 16 & 32 \\
Share Cropping & 31 & 62 \\
\hline Total & $\mathbf{5 0}$ & $\mathbf{1 0 0}$ \\
\hline
\end{tabular}

\section{Years in Farming}

More than one-third (36\%) of the respondents have been farming for 20 years with some $(26 \%)$ of them for 5 to 10 years. One-sixth $(16 \%)$ of them have been in rice farming for 21 to 30 years and more than one-eight (14\%) for 2 years and above. Lastly, less than one-eight $(6 \%)$ of them have been farming for 3 years and above and very few $(2 \%)$ of them for 31 years and above. Despite the fact that majority of the respondents have farmed for over 10 years, they are still economically deficient and not all have achieved land ownership. 
Table 9: Frequency and Percentage Distribution of the Respondents according to Years in Farming

\begin{tabular}{lll}
\hline Average Farming Land & Frequency $\mathbf{( f )}$ & Percentage $\mathbf{( \% )}$ \\
\hline 5 to 10 years & 13 & 26 \\
11 to 20 years & 18 & 36 \\
21 to 30 years & 8 & 16 \\
31 and above & 1 & 2 \\
Others (2 years above) & 7 & 14 \\
Others (3 years above) & 3 & 6 \\
\hline Total & $\mathbf{5 0}$ & $\mathbf{1 0 0}$ \\
\hline
\end{tabular}

\section{Level of Rice Production}

\section{Rice Classification}

Almost all $(96 \%)$ of the respondents irrigate their farms while the rest $(4 \%)$ of them do not since their farms are rain-fed. It implies that most of the respondents depend largely on irrigation as source of water for their farms. Those who do otherwise may have encountered challenges since there is no consistent supply of water due to the fact that the occurrence of rain is intermittent.

Table 10: Frequency and Percentage Distribution of the Respondents according to Rice Classification

\begin{tabular}{lll}
\hline Rice Classification & Frequency $(\mathbf{f})$ & Percentage $\mathbf{( \% )}$ \\
\hline Irrigated & 48 & 96 \\
Rain-fed & 2 & 4 \\
\hline Total & $\mathbf{5 0}$ & $\mathbf{1 0 0}$ \\
\hline
\end{tabular}

\section{Irrigation Sources}

Almost all $(90 \%)$ of respondents responded that their source of irrigation is the river while no one uses electric pumps. Moreover, less than one-eight $(10 \%)$ of them disclosed that their irrigation still depends on the rain. It implies that the irrigation needed for the rice fields depend on river sources.

Table 11: Frequency and Percentage Distribution of the Respondents according to Irrigation Sources

\begin{tabular}{lll}
\hline Rice Classification & Frequency (f) & Percentage (\%) \\
\hline River & 40 & 90 \\
Pump & - & - \\
Rain-fed & 5 & 10 \\
\hline Total & $\mathbf{5 0}$ & $\mathbf{1 0 0}$ \\
\hline
\end{tabular}

\section{Land Type}

More than half $(56 \%)$ of the respondents said that they farm in an upland while only less than half $(44 \%)$ of them are in lowland. It implies that the land type of the respondents' rice fields is upland.

Table 12: Frequency and Percentage Distribution of the Respondents' Land Type

\begin{tabular}{lll}
\hline Rice Classification & Frequency (f) & Percentage (\%) \\
\hline Upland & 28 & 56 \\
Lowland & 22 & 44 \\
\hline Total & $\mathbf{5 0}$ & $\mathbf{1 0 0}$ \\
\hline
\end{tabular}

\section{Roles Performance in Gender Dynamics}

Table 13 shows that more than half $(58 \%)$ of the respondents reported that their role in rice farm8ng is farm manager while less than half (44\%) of them are decision makers. More than one third $(38 \%)$ of them are on marketing of the rice and more than a third $(38 \%)$ of them are harvesters. Lastly, one-eight $(12 \%)$ of them are paid workers. It implies that the roles farmers perform in rice farming are farm manager and decision maker. Odlrup (2002) pointed out that women tried to reconstruct their identity in the field of agriculture. 
Table 13: Frequency and Percentage Distribution and Rank Analysis of the Respondents' Roles in Gender Dynamics

\begin{tabular}{|c|c|c|}
\hline $\begin{array}{l}\text { Roles Performance in } \\
\text { Gender Dynamics }\end{array}$ & Frequency (f) & Percentage $(\%)$ \\
\hline Unpaid Worker & - & - \\
\hline Paid Worker & 6 & 12 \\
\hline Marketing & 19 & 38 \\
\hline Researcher & - & - \\
\hline Decision Maker & 22 & 44 \\
\hline Harvester & 19 & 38 \\
\hline Farm Manager & 29 & 58 \\
\hline
\end{tabular}

*Multiple Responses

\section{Problems Encountered by the Farmers}

The respondents enumerated problems in rice farming. All of them (100\%) revealed that they lack information needs and encounter insufficient agricultural extension activities. Almost all of the respondents $(96 \%)$ also lack proper training in rice farming, while more than three-fourths $(86 \%)$ lack new rice farming technology. Lastly, more than two-thirds $(70 \%)$ have insufficient funds.

The findings imply that male and female rice farmers face various problems in performing their roles. They all lack information and do not have sufficient agricultural extension activities, which obviously cause the deterioration of their productivity in rice farming. More importantly, lack of proper training and farming technology would expectedly result in low income because they do not have alternative ways to boost the quality of their farms and the amount of harvest. Njuki, Kaaria, Chamunorwa and Chiuri (2011) recommended in their study that institutions or any organization related to farmers should use various strategies to link farmers to market. Jost, Kyazze, Naab, Neelormi, Kinyangi, and Zougmore (2015) emphasize in their study that farmers should be educated or trained also about the effect of climate to farming so that they can determine verities of planting maerials suited to the climatic conditions of their area. According to them this could be done through farmers-to-farmers learning or extension services which to be provided by institutions or organizations. Coping mechanisms will be enhanced when farmers are exposing to agricultural training programs and other farming-related extensions (Mehar, Mittal and Prasad, 2016)

Table 14: Frequency, Percentage Distribution and Rank Analysis of the Problems Encountered by the Respondents

\begin{tabular}{lll}
\hline Problems Encountered & Frequency (f) & Percentage (\%) \\
\hline Do not have access to water & - & - \\
Difficult in securing land tenure & - & - \\
Difficult in marketing the product & 2 & 4 \\
Insufficient funds & 35 & 70 \\
Lack of proper training in rice farming & 46 & 92 \\
Lack of quality of education for children & 3 & 6 \\
Too old to be efficient at work & 14 & 28 \\
Gender Discrimination & 13 & 26 \\
Lack of knowledge on rice farming & 48 & 96 \\
Ineffective communication to farmers & - & - \\
Lack of new rice farming technology & 43 & 86 \\
Insufficient agricultural extension activities & 50 & 100 \\
Lack of information needs & 50 & 100 \\
Rapid transition change & 23 & 46 \\
Spouse do not participate in rice farm activities & 11 & 22 \\
\hline
\end{tabular}

*Multiple Responses

\section{Summary of Findings}

Based on the gathered data, the followings are the major findings of the study:

1. More than one-third (38\%) of the respondents were 41 to 50 years old.

2. Most of the respondents $(62 \%)$ are male.

3. More than three-fourths $(86 \%)$ of the respondents are married. 
4. More than half (56\%) of the respondents have an incomplete elementary education.

5. More than half $(54 \%)$ of the respondents have a household size more than 6 members.

6. More than half (52\%) of the respondents have a monthly income of 5,000 to 10,000 .

7. More than half $(56 \%)$ of the respondents have farm size of 1 to 2 hectares.

8. Less than two-thirds $(62 \%)$ of the respondents do share cropping.

9. More than one-third (36\%) of the respondents have been farming for 11 to 20 years.

10. Almost all $(96 \%)$ of the respondents classify their rice as irrigated.

11. Almost all $(90 \%)$ of the respondents use river as source of irrigation.

12. More than half $(56 \%)$ of the respondents' farm in upland.

13. More than half $(58 \%)$ of the respondents perform their roles in gender dynamics as farm managers while less than half $(44 \%)$ of them are decision makers.

14. All respondents revealed they lack information needs and agricultural extension activities while almost all lack of knowledge of rice farming $(96 \%)$ and lack proper training $(92 \%)$.

\section{Conclusions}

Based on the findings of the study, the following conclusions were drawn:

1. Most of the farmers of Barangay Pendulonan, MunaiLanao del Norte are 41 to 50 years old, male, married, incomplete elementary education, have a household size of more than 6 members, have a monthly income of 5,000 to 10,000, have a farm-size of 1 to 2 hectares, are share cropping, and have average farming experience of 11 to 20 years.

2. Most of the farmers of Barangay Pendulonan, MunaiLanao del Norte irrigate their farms through the river farm in an upland.

3. Most of the farmers of Barangay Pendulonan, MunaiLanao del Norte have important roles in gender dynamics because they are farm managers, decision makers, marketers, and harvesters.

4. Most of the farmers of Barangay Pendulonan, MunaiLanao del Norte encounter considerably enormous problems in farming such as lacks information needs, insufficient agricultural extension activities, lack of knowledge in rice farming, and lack of proper training.

\section{Recommendation}

Based on the drawn conclusions, the following recommendations are suggested:

1. To make sure that the farmers have good quality of crops, there must be an agriculturist or extensions who will guide them to grow varieties of quality rice.

2. To have a high income, the municipal government must provide a high quality of rice to the farmers not only in pendulonan but also in other barangays.

3. A similar study should be conducted in other municipalities to evaluate the effectiveness of gender dynamics in rice farming.

4. Agriculturist and extension workers should monitor the farmers in order to know their problems in their field and to provide farmers with proper trainings in rice farming, technology for better production, and others.

5. The department of agriculture must conduct seminars on new methods, strategies, and new technologies to farmers and, most importantly, support them financially.

\section{References}

Gasson, R., \& Winter, M. (1992). Gender Relations And Farm Household Pluriactivity. Journal Of Rural Studies, 8(4), 387-397, doi: https://doi.org/10.1016/0743-0167(92)90052-8.

Jost, C., Kyazze, F., Naab, J., Neelormi, S., Kinyangi, J., and Zougmore, R. ( 2015). Understanding Gender Dimensions of Agriculture and Climate Change in Smallholder Farming Communities. Climate and Development, 8(2), 133-144, doi: https://doi.org/10.1080/17565529.2015.1050978

Meralao, V. A. (1992). Female-Headed Households in the Philippines. Pbilippine Sociological Review, 40(1-4), 4656.

Njuki, J., Kaaria, S., Chamunorwa, A., and Chiuri, W. (2011). Linking Smallholder Farmers to Markets, Gender and Intra-Household Dynamics: Does the Choice of Commodity Matter? European Journal of Development Research, 23(3).

Mehar, M., Mittal, S., Prasad, N. (2016) Farmers Coping Strategies For Climate Shock: Is it differentiated by gender? Journal of Rural Studies, 44, 123-131, doi: https://doi.org/10.1016/j.jurstud.2016.01.001.

Oldrup, H. (2002). Women Working off the Farm: Reconstructing Gender Identity in Danish Agriculture. Journal of the European Society for Rural Sociology, 39(3), doi: https://doi.org/10.1111/1467-9523.00112

Pandey, S., Byerlee, D., Dobermann, A., Mohanty, S., Rozelle, S., \& Hardy, B. (2010). Rice in the Global Economy: Strategic Research and Policy Issues for Food Security, 477. 
Quisumbing, A. R., Meinzen-Dick, R., Raney, T. L., Croppendstedt, A., Behrman, J. A., \& Peterman, A. (2014). Closing the knowledge gap on gender in agriculture. In Gender in Agriculture (pp. 3-27). Springer, Netherlands.

Raynolds, L. T. (2002). Wages for Wives: Renegotiating Gender and Production Relations in Contract Farming in the Dominican Republic. World Development, 30(5), 783-798, doi: https://doi.org/10.1016/S0305-750X(02)00008-6.

RDoss, C. (2001). Designing Agricultural Technology for African Women Farmers: Lessons from 25 Years of Experience. World Development, 29(12), 2075-2092, doi: https://doi.org/10.1016/S0305750X(01)00088-2.

Swaminathan, H., Lahoti, R., \& Suchitra, J. Y. (2012). Women's Property, Mobility, $\quad$ and Decision making: Evidence from Rural Kamataka, India. International Food Policy Research Institute discussion paper (01188). 